\title{
New large-scale production route for synthesis of lithium nickel manganese cobalt oxide
}

\author{
Katja Fröhlich $^{1}$ (D) $\cdot$ Evgeny Legotin $^{1} \cdot$ Frank Bärhold $^{2} \cdot$ Atanaska Trifonova $^{1}$
}

Received: 1 February 2017 /Revised: 9 May 2017 / Accepted: 10 May 2017 / Published online: 7 June 2017

(C) The Author(s) 2017. This article is an open access publication

\begin{abstract}
The spray roasting process is recently applied for production of catalysts and single metal oxides. In our study, it was adapted for large-scale manufacturing of a more complex mixed oxide system, in particular symmetric lithium nickel manganese cobalt oxide $\left(\mathrm{LiNi}_{1 / 3} \mathrm{Co}_{1 / 3} \mathrm{Mn}_{1 / 3} \mathrm{O}_{2}-\mathrm{NMC}\right)$, which is already used as cathode material in lithium-ion batteries. An additional lithiation step was coupled with the main process in order to obtain the desired layered structure. Thermogravimetric analysis and high-temperature X-ray diffractometry built the basis for determining suitable synthesis temperature regions for the used chloride precursors and the post-treatment step. The optimized process was proven on an industrial pilot line where a setup for minimum production capacity of $12 \mathrm{~kg} \mathrm{~h}^{-1}$ was possible. The powder obtained directly after roasting had a very striking morphology compared to the final lithiated product. Hollow aggregates $(\geq 250 \mu \mathrm{m})$ with overall $10.926 \mathrm{~m}^{2} \mathrm{~g}^{-1}$ surface area and a pore diameter of $3.396 \mathrm{~nm}$ were observed. Their well-faceted primary particles were converted into nanosized spheres after lithiation, building a few micrometer big high-porous agglomerates. Actual composition was verified by inductively coupled plasma atomic emission spectroscopy analysis, and the crystal structure and corresponding unit cell parameters were identified and confirmed by Rietveld fit of the derived $\mathrm{X}$-ray diffraction pattern. The initial electrochemical measurements show a $149-\mathrm{mAh} \mathrm{g}^{-1}$ discharge capacity, as determined from cyclic voltammetry.
\end{abstract}

Katja Fröhlich

katja.froehlich@ait.ac.at

1 Electric Drive Technologies, Austrian Institute of Technology $\mathrm{GmbH}$, Giefinggasse 2, 1210 Vienna, Austria

2 Andritz AG, Eibesbrunnergasse 20, 1120 Vienna, Austria
Keywords NMC $\cdot$ Spray roasting $\cdot$ Li-ion battery $\cdot$ Cathode

\section{Introduction}

The electrification of the transport sector is a necessary and very important step for the reduction of $\mathrm{CO}_{2}$ emissions. Electric vehicles on the road are still very limited in number. The main reasons for the low acceptance are their high costs and limited driving ranges. Improvement in both categories can only be achieved with high-performance batteries at reasonable prices. To meet these market requirements, not only new materials are needed but also sustainable and efficient processes for their production. The total energy storage costs depend mainly on the cathode material, since the cathode makes up for about $42 \%$ of the battery. Moreover, according to "Avicenne Energy's" market forecast, a long-term reduction of cost per kilowatt-hour by $40 \%$ is possible if lithium nickel manganese cobalt oxide (NMC) cathode materials are used [1]. A future robust and flexible production process of the material will therefore have great impact on the TCO (total cost of ownership).

Due to its layered structure, NMC provides optimal diffusion pathways for fast lithium intercalation and deintercalation during charging and discharging [2]. Nowadays, this already commercialized electrode active material is synthesized in different ways, such as solid state [3-5], sol-gel routes [6-8], the co-precipitation method [9-12], and combinations of them. All these multi-step syntheses have in common that they are very expensive in terms of time and energy consumption.

There are several advantages of spray techniques over these methods: the high throughput, easy-to-handle, scalable, continuous one-step process, a broad spectrum of precursor's solutions to choose from, etc. [13, 14]. Additionally, the process of flame-assisted spray pyrolysis is well known in industry 
Table 1 Characterization methods and corresponding equipment

\begin{tabular}{lll}
\hline Technique & Equipment & Software/other comments \\
\hline $\begin{array}{l}\text { Thermogravimetric and differential } \\
\text { thermal analysis (TG/DTA) }\end{array}$ & NETZSCH STA 429 & NETZSCH Proteus, version 6.1.0d \\
$\begin{array}{l}\text { Gas adsorption } \\
\text { Laser diffraction }\end{array}$ & Quantachrome Instruments, Quantachrome iQ & AsiQwin; analysis gas: Nitrogen 5.0 \\
X-ray diffraction & CILAS 1190 particle size analyzer & Particle Expert; Disperbyk-190 additive \\
$\begin{array}{l}\text { Rietveld refinement } \\
\text { ICP-AES }\end{array}$ & PANalytical X'Pert Pro, X'Celerator & Cu-K $\alpha$ radiation; high-temperature chamber \\
Scanning electron microscopy & GSAS [25] & EXPGUI interface [26]
\end{tabular}

[15], due to its wide application in production of metals, oxides, nitrides, borides, and battery materials for Li-S batteries [16]. It was therefore chosen for further adaptation for battery material production using mixed metal precursors in a single solution.

According to the literature, some mixed metal compounds have been successfully synthesized via spray pyrolysis experiments in different laboratories [13], mostly using nitrates [17-19] or acetates [20] as precursors, and additional chelating agents $[21,22]$. In every instance, a post-treatment of the initial spray pyrolysis product was necessary. The post-treatment typically includes calcination of either the pure spray pyrolysis product or its mixture with a lithium precursor (mostly $\mathrm{LiOH}$ ), depending on whether or not lithium is introduced at the spray pyrolysis step. In contrast to the reported research activities in this field, chloride precursors have not been used yet, and the information about the resulting battery material quality, in particular NMC, produced through this method in one large-scale batch is missing as well. This publication provides information about these matters.

Nickel, cobalt, and manganese chlorides can be completely oxidized under normal spray roasting conditions [23]. At the same time, pyrohydrolysis of monovalent chlorides, such as $\mathrm{LiCl}$, does not proceed below $2000{ }^{\circ} \mathrm{C}$, whereas the temperature in the middle part of spray roasters usually varies between 600 and $900{ }^{\circ} \mathrm{C}$ [24]. A one-step production of the layered

Table2 Crystallographic parameters of NMC

\begin{tabular}{ll}
\hline Parameter & Value \\
\hline Crystal system & Hexagonal \\
Space group & R-3m \\
$a(\AA)$ & 2.86 \\
$b(\AA)$ & 2.86 \\
$c(\AA)$ & 14.227 \\
$\alpha\left(^{\circ}\right)$ & 90.00 \\
$\beta\left(^{\circ}\right)$ & 90.00 \\
$\gamma\left({ }^{\circ}\right)$ & 120.00 \\
\hline
\end{tabular}

NMC material by decomposition of their precursor chlorides therefore does not seem straightforward, and the postlithiation step seems indispensable. Therefore, post-treatment for lithiation was applied in the presented process.

In our research, thermogravimetric data and preliminary experiments built the basis for the parameter setup. The cathode material NMC was synthesized on an industrial scale via spray roasting and post-treatment for lithiation from a chloride precursor solution. The composition was verified by inductively coupled plasma atomic emission spectroscopy (ICPAES) analysis and the specific discharge capacities were determined from cyclic voltammetry measurements.

\section{Experimental}

\section{Thermogravimetric measurements}

A thermogravimetric (TG) measurement of the mixed metal chloride precursors $\mathrm{NiCl}_{2} \cdot \mathrm{CoCl}_{2} \cdot \mathrm{MnCl}_{2} \cdot \mathrm{nH}_{2} \mathrm{O}$ (SigmaAldrich, $\geq 98 \%$ ) was conducted in order to estimate the temperature required for complete decomposition. Nickel, cobalt, and manganese chlorides in a molar ratio of 1:1:1 were dissolved in a small amount of deionized water. The solution was dried at $60{ }^{\circ} \mathrm{C}$ in air atmosphere to form a solid film. The film was carefully scraped off and ground in a mortar. For the measurement, a precise quantity of sample $(60 \mathrm{mg})$ was placed into a microsized alundum crucible and heated up to $950{ }^{\circ} \mathrm{C}$ at a rate of $5{ }^{\circ} \mathrm{C} \mathrm{min}{ }^{-1}$ in synthetic air flow (80 vol\% $\mathrm{N}_{2}, 20$ vol\% $\mathrm{O}_{2}$ ).

\section{Synthesis}

Metal chlorides were chosen as precursors due to the wellknown process of metal oxide synthesis from chloride solutions and further hydrochloric acid recovery from the outlet gases. An aqueous solution of $\mathrm{Mn}^{2+}, \mathrm{Ni}^{2+}$, and $\mathrm{Co}^{2+}$ was prepared from $\mathrm{MnCl}_{2} \cdot 4 \mathrm{H}_{2} \mathrm{O}$ (Sigma-Aldrich, 98\%), $\mathrm{NiCl}_{2}$. $6 \mathrm{H}_{2} \mathrm{O}$ (Sigma-Aldrich, 98\%), and $\mathrm{CoCl}_{2}$ (Sigma-Aldrich, 
$\mathrm{DTA} /(\mu \mathrm{V} / \mathrm{mg})$

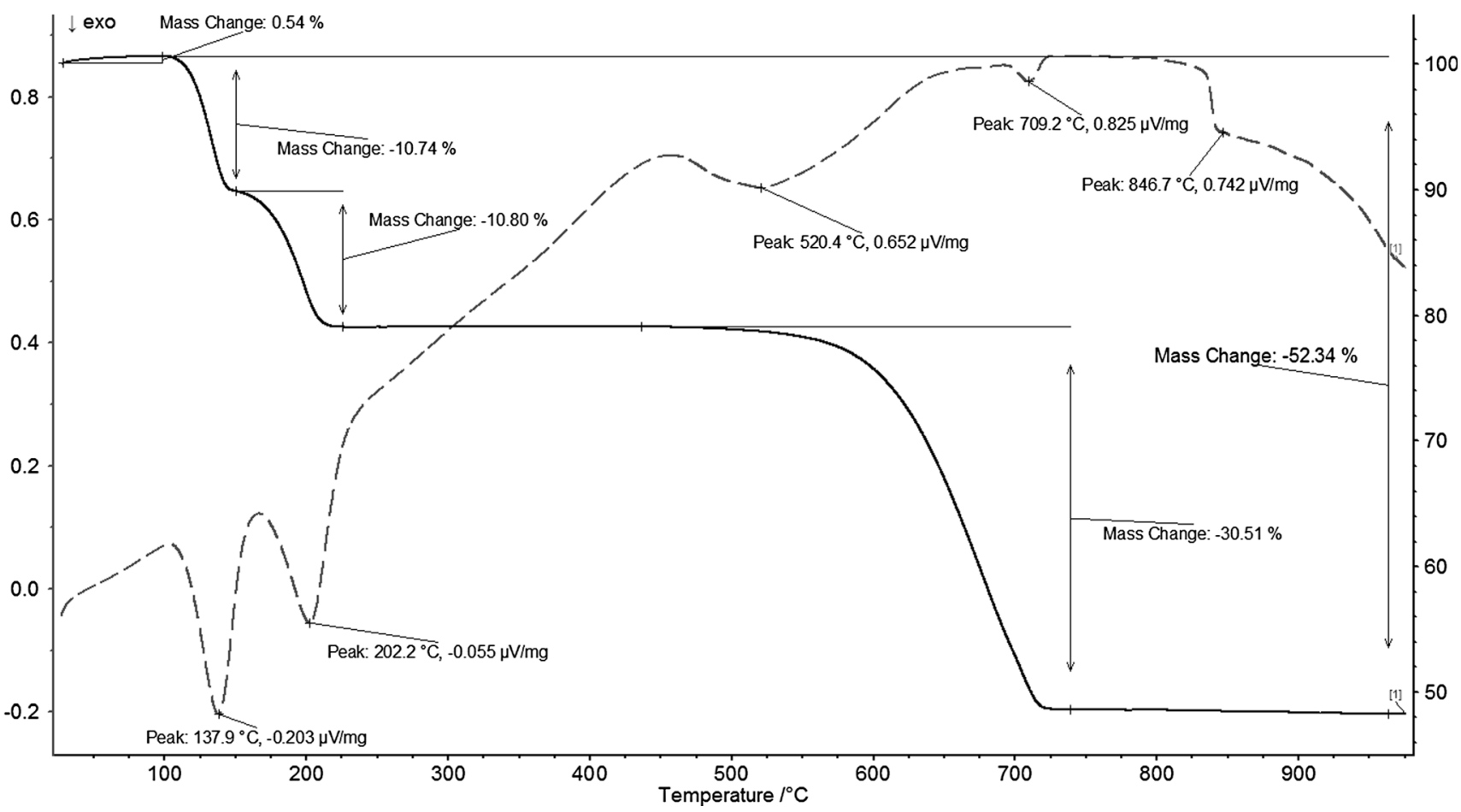

Fig. $1 \mathrm{TG}$ and DTA curves for the mixed precursor $\mathrm{NiCl}_{2} \cdot \mathrm{CoCl}_{2} \cdot \mathrm{MnCl}_{2} \cdot \mathrm{xH}_{2} \mathrm{O}$

$97 \%$ ) in a stoichiometric ratio of 1:1:1. The solution was preconcentrated to achieve a density of $1.15 \mathrm{~g} \mathrm{~cm}^{-3}$. The solution was sprayed through a nozzle at the top into the roasting reactor chamber, which was heated by a burner (burning gases: natural gas and air) continuously so that two temperature areas were achieved $\left(500-700^{\circ} \mathrm{C}\right)$. The droplets descended in a swirling flow and dried up, and the solutes were pyrohydrolyzed.

The process lasted 4 hours until the pilot line was shut down and the product was removed from the outlet of the reaction chamber. Meanwhile, the hydrochloric acid was recovered as a side product from the gas phase through the exhaust outlet. The intermediate product was further lithiated with $\mathrm{LiOH} \cdot \mathrm{H}_{2} \mathrm{O}$ (Alfa Aesar, 98\%) at higher temperature to achieve the required crystallinity and desired layered $\alpha$ $\mathrm{NaFeO}_{2}$ structure. For this purpose, the intermediate product was mixed with $\mathrm{LiOH} \cdot \mathrm{H}_{2} \mathrm{O}$ for 3 hours in a stainless steel planetary mill. The powder mixture was then heated for 10 hours in a muffle oven under ambient conditions.

\section{Powder characterization}

For powder characterization of the obtained intermediate and final products, different measurements were performed. The techniques and corresponding equipment are summarized in Table 1.

To determine the optimal synthesis temperature of the lithiation step, a high-temperature chamber was installed into the X-ray diffractometer. The temperature chamber was set to a heating rate of $5{ }^{\circ} \mathrm{C} \mathrm{min}^{-1}$ under air atmosphere. X-ray diffraction patterns of the mixture of the intermediate product and the lithium precursor were recorded at every $100{ }^{\circ} \mathrm{C}$ step during the heating process.

Table 3 Interpretation of thermogravimetric data for the mixed precursor

\begin{tabular}{|c|c|c|c|c|}
\hline \multirow[t]{2}{*}{ Stage } & \multirow[t]{2}{*}{ Chemical reaction } & \multirow[t]{2}{*}{ Temperature interval, ${ }^{\circ} \mathrm{C}$} & \multicolumn{2}{|c|}{ Loss in mass, $\%$} \\
\hline & & & Observed & Theoretical \\
\hline 1 & $\mathrm{NiCl}_{2} \cdot \mathrm{CoCl}_{2} \cdot \mathrm{MnCl}_{2} \cdot 6 \mathrm{H}_{2} \mathrm{O}=\mathrm{NiCl}_{2} \cdot \mathrm{CoCl}_{2} \cdot \mathrm{MnCl}_{2} \cdot 3 \mathrm{H}_{2} \mathrm{O}+3 \mathrm{H}_{2} \mathrm{O}$ & $100-150$ & 10.7 & 11.0 \\
\hline 2 & $\mathrm{NiCl}_{2} \cdot \mathrm{CoCl}_{2} \cdot \mathrm{MnCl}_{2} \cdot 3 \mathrm{H}_{2} \mathrm{O}=\mathrm{NiCl}_{2} \cdot \mathrm{CoCl}_{2} \cdot \mathrm{MnCl}_{2}+3 \mathrm{H}_{2} \mathrm{O}$ & $150-225$ & 10.8 & 11.0 \\
\hline 3 & $\mathrm{NiCl}_{2} \cdot \mathrm{CoCl}_{2} \cdot \mathrm{MnCl}_{2}+1.95 \mathrm{O}_{2}=" \mathrm{NiCoMnO}_{3.9} "+3 \mathrm{Cl}_{2}$ & $440-725$ & 30.5 & 30.5 \\
\hline Total & $\mathrm{NiCl}_{2} \cdot \mathrm{CoCl}_{2} \cdot \mathrm{MnCl}_{2} \cdot 6 \mathrm{H}_{2} \mathrm{O}+1.95 \mathrm{O}_{2}=" \mathrm{NiCoMnO}_{3.9} "+6 \mathrm{H}_{2} \mathrm{O}+3 \mathrm{Cl}_{2}$ & & 52.3 & 52.4 \\
\hline
\end{tabular}



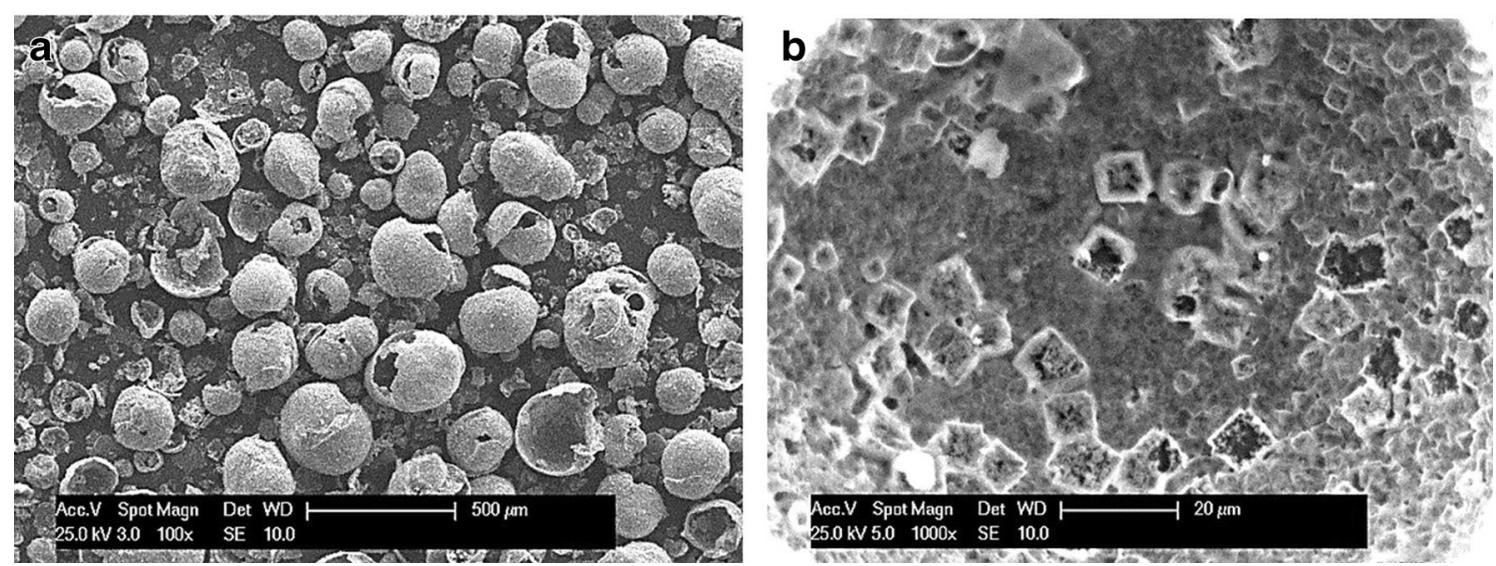

Fig. 2 SEM images of the intermediate product before the lithiation step. a Large hollow particles. b Inner shell of the particles show crystallites

For structural analysis using Rietvield fit, a polynomial background, scale factor, zero point, absorption correction, coefficients for the peak shape function, and cell parameters were refined. In the starting model, $3.34 \%$ of cation mixing between $\mathrm{Ni}$ and Li sites was assumed (which is likely due to their similar ionic radii of 0.69 and $0.76 \AA$, respectively) and the basic structural parameters proposed by Nazar et al. were taken into account $[27,28]$ (see Table 2).

\section{Electrochemical characterization}

To prove electrochemical activity, slurries were prepared from the corresponding active material (NMC), carbon black (Super P, Timcal), and binder (polyvinylidene fluoride, PVDF, MTI) with a ratio of 80:10:10 (w/w). The active material was ball-milled in a planetary mill with the carbon black for 3 hours and added to the PVDF, which had been dissolved before in $N$-methyl-2-pyrrolidone (NMP, Sigma-Aldrich, 99.5\%). The slurry was mixed several hours at $600 \mathrm{rpm}$ in order to achieve good homogeneity. The electrode coating was performed using the doctor-blade technique. The current collector was aluminum foil $(15 \mu \mathrm{m}, \mathrm{MTI})$ and wet tapes had a thickness of $120 \mu \mathrm{m}$. The coated electrodes were further dried and hot-pressed to a final thickness of $40 \mu \mathrm{m}$. Electrodes with a diameter of $15 \mathrm{~mm}$ were cut, dried again at $120{ }^{\circ} \mathrm{C}$ for several hours under a vacuum, and transferred into an argon-filled glove box (MBraun). Half-cell measurements were performed using lithium metal as counter electrode

Table 4 Average values (AV) and standard deviations (SDEV) of the composition derived by ICP-AES

\begin{tabular}{|c|c|c|c|c|c|c|}
\hline & \multicolumn{2}{|c|}{$\mathrm{Ni}[\mathrm{wt} \%]$} & \multicolumn{2}{|c|}{ Co $[w t \%]$} & \multicolumn{2}{|c|}{$\mathrm{Mn}[\mathrm{wt} \%]$} \\
\hline & $\mathrm{AV}$ & SDEV & $\mathrm{AV}$ & SDEV & $\mathrm{AV}$ & SDEV \\
\hline Intermediate product & 24.4 & 0.1 & 24.6 & 0.2 & 24.6 & 0.1 \\
\hline
\end{tabular}

and $1 \mathrm{M} \mathrm{LiPF}_{6}$ in EC/DMC 1:1 (w/w) (BASF, battery grade) as electrolyte. Glass fiber separators were used after drying (Whatman). Cyclic voltammetry measurements were performed at a scan rate of $100 \mu \mathrm{V} \mathrm{s}^{-1}$ in the potential range between 3 and $4.2 \mathrm{~V}$ using a BioLogic Potentiostat SP300, and the specific capacities were calculated from the derived currents of the third cycle. Type 2032 coin cells were used for cycle ability tests at $0.1 \mathrm{C}$ for 45 cycles using a Maccor Series 4000 between 3 and $4.2 \mathrm{~V}$.

\section{Results and discussion}

\section{Thermogravimetric measurements}

The obtained TG and differential thermal analysis (DTA) curves are presented in Fig. 1.

Three steps can clearly be distinguished on the TG curve. The first two steps correspond to the elimination of crystallized water and the last one is the oxidation of the resulting anhydrous mixed chloride. The latter process begins at $440{ }^{\circ} \mathrm{C}$ and is completed at $725^{\circ} \mathrm{C}$. Table 3 summarizes the processed thermogravimetric data.

Oxygen content $x$ in the decomposition product $\mathrm{NiCoMnO}_{x}$ equals 3.9, as determined from thermogravimetric data. Interestingly, the decomposition product $\mathrm{NiCoMnO}_{3.9}$ undergoes some structural change at $839^{\circ} \mathrm{C}$, which appears as a jump on the DTA curve; it is not, however, seen on the TG curve. The anomaly might correspond to spinel dissociation as described for other Mn-rich spinels [29]. These measurements show that temperatures of at least $700{ }^{\circ} \mathrm{C}$ would be necessary for complete decomposition of $\mathrm{Ni}, \mathrm{Co}$, and $\mathrm{Mn}$ chlorides in a spray roasting process. The heating process during the TGA measurement is quite fast, so that lower temperatures with longer residence time might be applicable as well and reduce the energy consumption of the industrial equipment. 


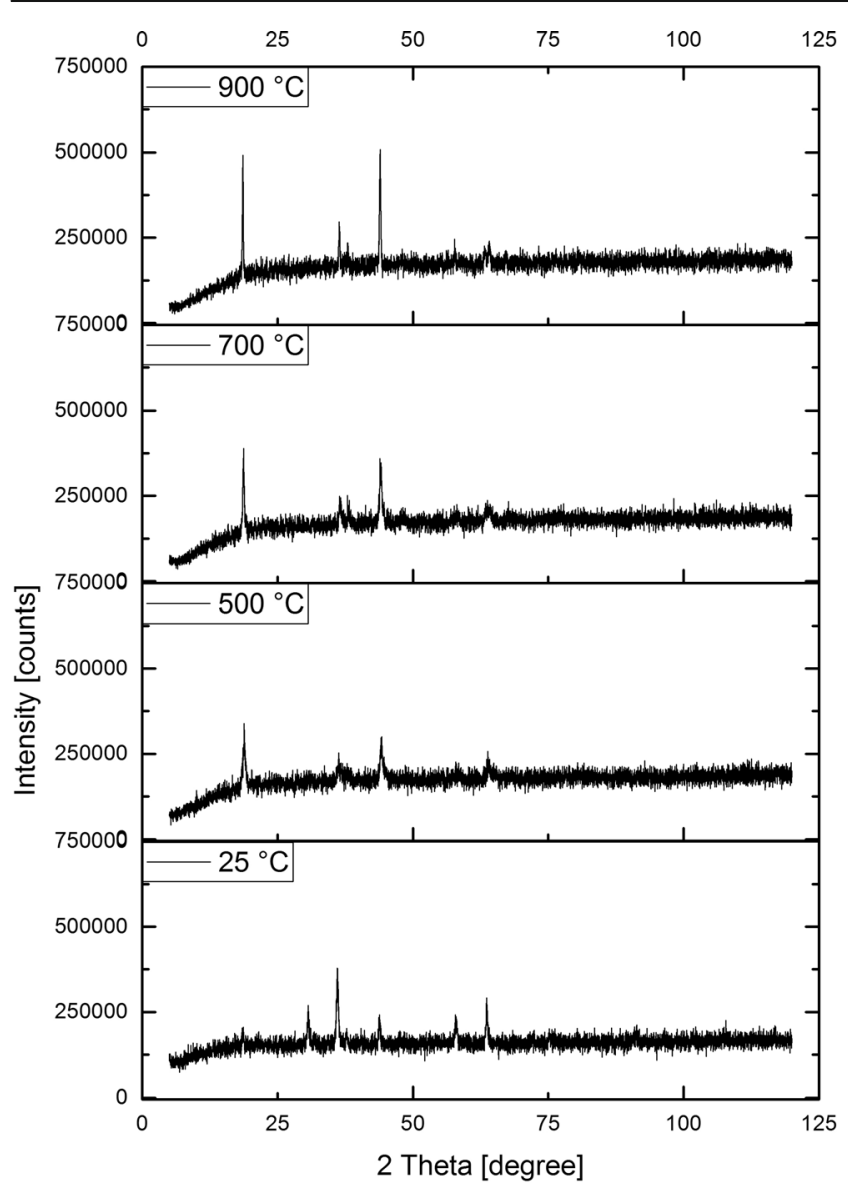

Fig. 3 X-ray diffraction pattern at selected temperatures of the intermediate product mixed with lithium precursor

\section{Synthesis}

As lithium chlorides are so stable that hydrolysis into metal oxide does not occur below $2000{ }^{\circ} \mathrm{C}$, and such temperatures are not practical for large-scale production, no lithium precursor was added in the synthesis at the pilot line. Therefore, a mixture of spinel type $\mathrm{M}_{3} \mathrm{O}_{4}$
$(\mathrm{M}=\mathrm{Ni}, \mathrm{Mn}, \mathrm{Co})$ oxides could be prepared in a first step in the reaction chamber of the pilot line. Scanning electron microscope (SEM) images of the intermediate product (see Fig. 2) show large hollow particles with an outer diameter of around $250 \mu \mathrm{m}$. The particles are partly cracked and might be easily destroyed through the process of post-lithiation and electrode preparation. The inner sides of the particles show cuboid-shaped crystallites with edge lengths below $10 \mu \mathrm{m}$.

ICP-AES measurements were performed to verify the actual composition of the intermediate product. Three measurements were performed and the average values (AV) together with the standard deviation (SDEV) are presented in Table 4.

Taking into account the standard deviations, the overall mixture seems to be homogeneous by elemental composition and there is no clear indication for enrichment of any of the transition metals in the pilot line.

$\mathrm{X}$-ray diffraction patterns from high-temperature chamber experiments were recorded at different temperatures to estimate the optimal lithiation temperature. Selected X-ray diffraction patterns are shown in Fig. 3.

It can be seen that the characteristic peaks starts to arise at around $500{ }^{\circ} \mathrm{C}$, but the well-crystallized structure becomes visible only at temperatures around $900{ }^{\circ} \mathrm{C}$. Therefore, this temperature was chosen for lithiation to achieve good crystallinity. Due to the evaporation of lithium around this temperature, a lithium precursor was used in excess to achieve the desired stoichiometry.

\section{Powder characterization}

SEM images of the final product are presented in Fig. 4.

The final powder has a completely different morphology compared to the intermediate product; small round particles on a nanometer scale were found instead of hollow spheres. The primary particle size seems well distributed from optical
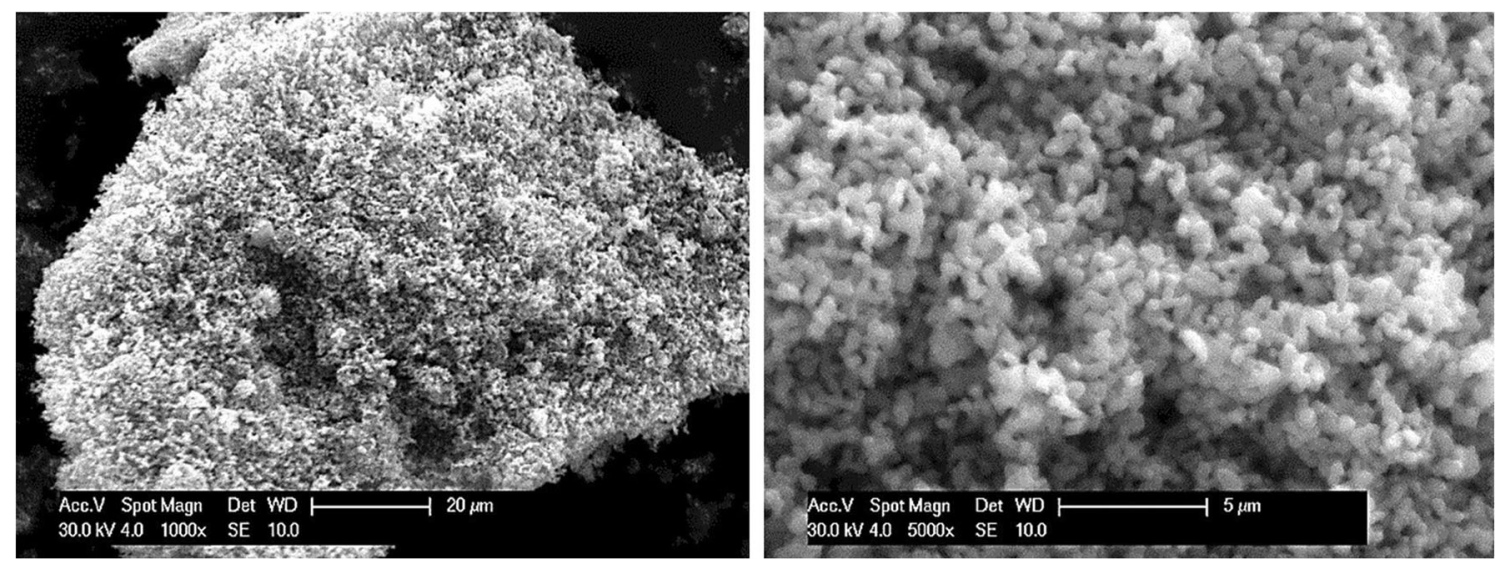

Fig. 4 SEM images of the final NMC product post-treated at $900{ }^{\circ} \mathrm{C}$ 
Table 5 Powder characteristics of synthesized NMC and intermediate product

\begin{tabular}{lcl}
\hline Parameter & Intermediate product & Final product \\
\hline Specific surface area $\left[\mathrm{m}^{2} \mathrm{~g}^{-1}\right]$ & 10.926 & 3.610 \\
Pore volume $\left[\mathrm{cm}^{3} \mathrm{~g}^{-1}\right]$ & 0.049 & 0.013 \\
Pore diameter $[\mathrm{nm}]$ & 3.396 & 3.068 \\
D10 $[\mu \mathrm{m}]$ & 0.42 & 0.42 \\
D50 $[\mu \mathrm{m}]$ & 3.83 & 1.50 \\
D90 $[\mu \mathrm{m}]$ & 11.38 & 6.41 \\
\hline
\end{tabular}
structural parameters for obtained product NMC from XRD
Table 6 Crystal

\begin{tabular}{ll}
\hline Parameter & Value \\
\hline Structural formula & $\alpha-\mathrm{NaFeO}_{2}$ \\
$a[\AA]$ & 2.866 \\
$c[\AA]$ & 14.257 \\
Volume $\left[\AA^{3}\right]$ & 101.411 \\
Density $\left[\mathrm{g} \mathrm{cm}^{-3}\right]$ & 4.740 \\
\hline
\end{tabular}

observation, having an overall similar radius. The concrete results of physico-chemical characterization of both the intermediate and the final product are presented in Table 5.

The specific surface area as well as the particle size decreased with lithiation. This is related to the breakup of the spheres which had been created within the spray roasting process. During ball milling, the particles broke, building into smaller spheres which then formed nanosized particles during lithiation.

$\mathrm{X}$-ray diffraction patterns of the final product were recorded for Rietveld refinement. All diffraction peaks can be indexed on the hexagonal R-3m model. The refinement of the NMC structure gave excellent fits, as shown in Table 6, with the corresponding fitted diffraction profile in Fig. 5.

\section{Electrochemical characterization}

Cyclic voltammetry measurements of fresh electrodes showed reversible reaction with an oxidation peak at $3.8 \mathrm{~V}$ and a reduction peak at $3.6 \mathrm{~V}$ (see Fig. 6), which correspond to the $\mathrm{Ni}^{2+/ 4+}$ redox reactions. The specific discharge capacity was calculated with $149 \mathrm{mAh} \mathrm{g}^{-1}$ from the third cycle.

The cycling tests after formation showed efficiency of $>99.9 \%$ within the first 45 cycles and a specific discharge capacity of $124.4 \mathrm{mAh} \mathrm{g}^{-1}$ in the last cycle. The specific capacities and cycle efficiencies over 45 cycles are presented in Fig. 7.

Taking into account the fact that no adjustment of the slurry preparation procedure or formula was performed, the real specific discharge capacity shows encouraging values for further attempts regarding this production route.

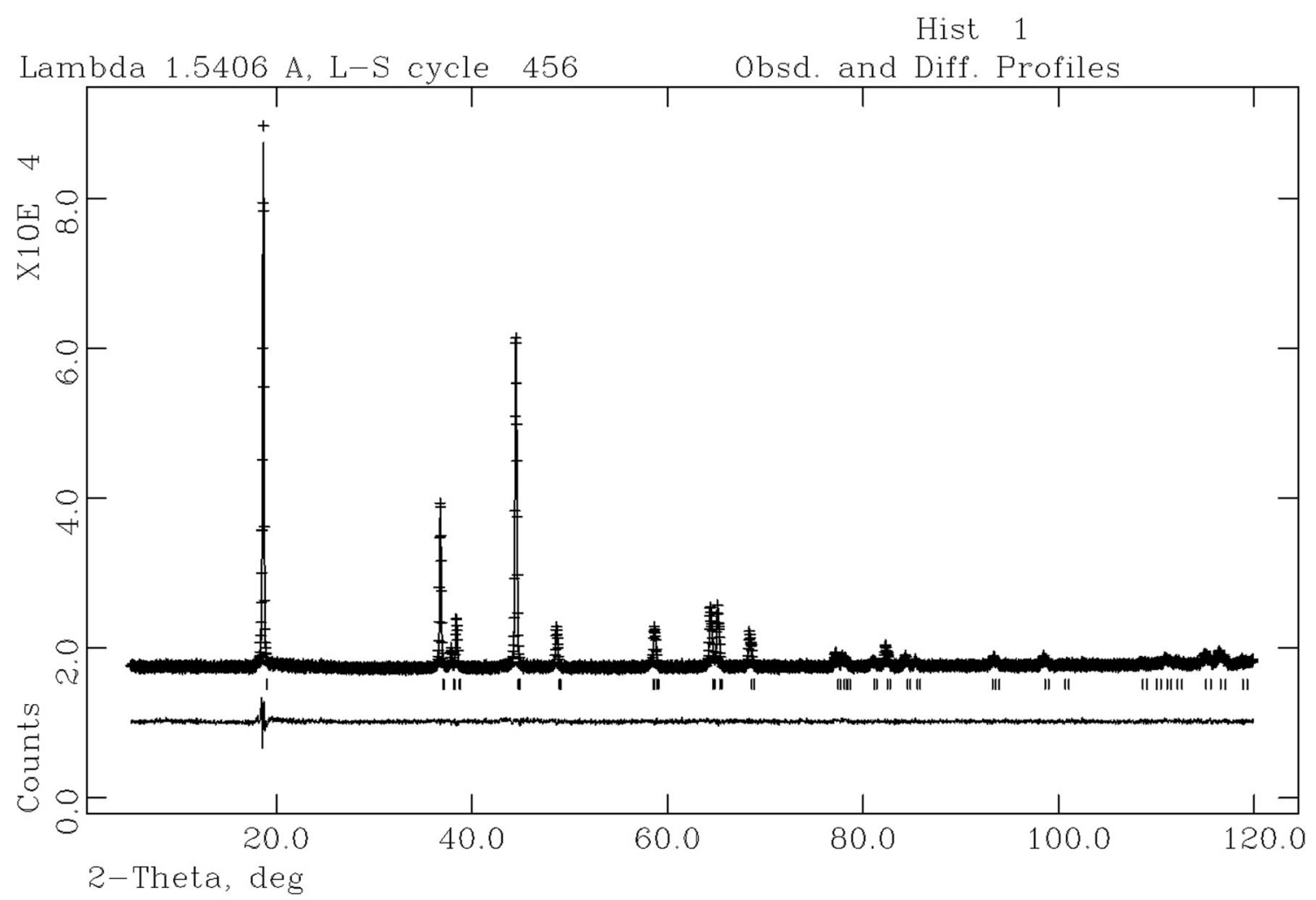

Fig. 5 Fitted diffraction profile of the obtained NMC 


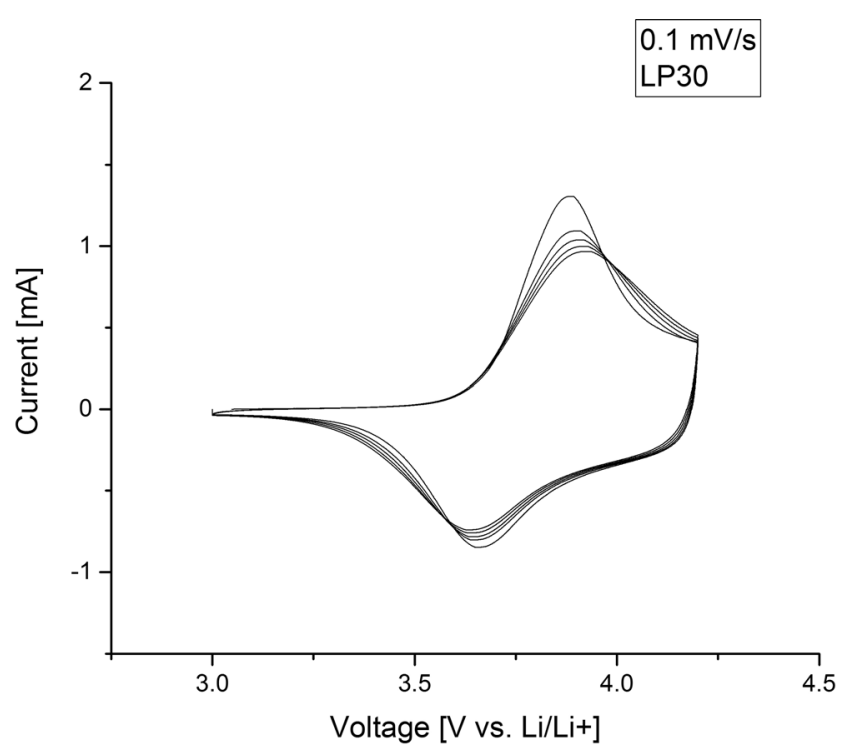

Fig. 6 Five cycles of the cyclovoltammetric measurements

\section{Conclusions}

Overall battery price is strongly influenced not only by the cell chemistry but also by the industrial production route of the components. As the cathode material accounts for nearly half of the overall battery costs, the synthesis route and conditions are crucial. Therefore, a new large-scale production route was chosen for NMC synthesis in our research. The well-known process of spray pyrolysis techniques for metal oxide production and additional hydrochloric acid recovery was adopted for battery material production.

From nickel, cobalt, and manganese chloride solutions, spinel type " $\mathrm{M}_{3} \mathrm{O}_{4}$ " was synthesized in a single step and successfully lithiated and transformed into layered NMC in a second step at $900{ }^{\circ} \mathrm{C}$ for $10 \mathrm{~h}$. Cyclic voltammetry



Fig. 7 First 45 cycles of obtained NMC versus lithium metal at $0.1 \mathrm{C}$, voltage range $3.0-4.2 \mathrm{~V}$ measurements showed a specific discharge capacity of $149 \mathrm{mAh} \mathrm{g}^{-1}$ at the third cycle. The cells showed good reversibility and long-term tests are ongoing and showed high efficiency $>99.9 \%$ until the 45 th cycle. At this point, it should be noticed that slurry preparation was not adjusted for the specific active material but that a generic formula was used for fast electrochemical screening. The lithiation step might be improved through lower temperatures or shorter sintering time but was not adjusted for now. The aim was to prove the feasibility of the whole process, which is currently being improved further through ongoing experiments.

Overall, the feasibility of the presented spray pyrolysis process with post-lithiation of mixed metal oxides at industrial scale was proven. The process can be performed continuously, which is a great improvement compared to conventional synthesis procedures. There are no individual batches, which reduces both processing time, energy consumption, and the number of necessary quality controls. In sum, this is expected to drive down cathode cost significantly; since cathodes account for about half of a battery's entire cost, noticeable savings are certainly to be expected. The virtually complete recovery of hydrochloric acid, which closes the loop, is another major positive aspect of the environmental impact of the entire production process.

The electrochemical activity as well as the physicochemical parameters is comparable to those of commercial $\mathrm{NMC}$ cathode materials. Improvement of the overall process through further experiments is ongoing.

Acknowledgements This work was financially supported by the Austrian Federal Ministry for Transport, Innovation and Technology (bmvit) and the Austrian Research Promotion Agency (FFG) through the project PyroBat, GA no. 848603 .

Open Access This article is distributed under the terms of the Creative Commons Attribution 4.0 International License (http:// creativecommons.org/licenses/by/4.0/), which permits unrestricted use, distribution, and reproduction in any medium, provided you give appropriate credit to the original author(s) and the source, provide a link to the Creative Commons license, and indicate if changes were made.

\section{References}

1. Pillot C (2012-2025) The worldwide rechargeable battery market, 22nd edn. Presented at the BATTERIES conference in 2012 in Nice, France

2. Dou S (2013) Review and prospect of layered lithium nickel manganese oxide as cathode materials for Li-ion batteries. J Solid State Electrochem 17:911-926

3. Hsieh C-T, Hsu H-H, Mo C-Y, Chen Y-F, Pai C-T (2015) Mediumfrequency induction sintering of lithium nickel cobalt manganese oxide cathode materials for lithium ion batteries. Solid State Ionics 270:39-46

4. Wang Z, Yin Y, Ren Y, Wang Z, Gao M, Ma T, Zhuang W, Lu S, Fan A, Amine K, Chen Z (2016) High performance lithiummanganese-rich cathode material with reduced impurities. Nano Energy 31:247-257 
5. Zhao C, Shen Q (2014) Organic acid assisted solid-state synthesis of $\mathrm{Li}_{1.2} \mathrm{Ni}_{0.16} \mathrm{Co}_{0.08} \mathrm{Mn}_{0.56} \mathrm{O}_{2}$ nanoparticles as lithium ion battery cathodes. Curr Appl Phys 14:1849-1853

6. Hernández A, Fabela S, Torres-González LC, Sánchez E (2008) Preparation and electrochemical behavior of sol-gel $\mathrm{LiNi}_{0.3} \mathrm{Co}_{0.70}-\mathrm{xM}_{\mathrm{x}} \mathrm{O}_{2}(\mathrm{M}=\mathrm{Mn}, \mathrm{Al})$. Ceram Int 34:225-229

7. Zhang W, Liu H, Hu C, Zhu X, Li Y (2008) Preparation of layered oxide $\mathrm{Li}\left(\mathrm{Co}_{1 / 3} \mathrm{Ni}_{1 / 3} \mathrm{Mn}_{1 / 3}\right) \mathrm{O}_{2}$ via the sol-gel process. Rare Metals 27:158-164

8. Kiziltas-Yavuz H, Herklotz M, Hashem AM, Abuzeid HM, Schwarz B, Ehrenberg H, Mauger A, Julien CM (2013) Synthesis, structural, magnetic and electrochemical properties of $\mathrm{LiNi}_{1 / 3} \mathrm{Mn}_{1 / 3} \mathrm{Co}_{1 / 3} \mathrm{O}_{2}$ prepared by a sol-gel method using table sugar as chelating agent. Electrochim Acta 113:313-321

9. Ma S, Hou X, Lin Z, Huang Y, Gao Y, Hu S, Shen J (2015) One-pot facile co-precipitation synthesis of the layered $\mathrm{Li}_{1+}$ ${ }_{x}\left(\mathrm{Mn}_{0.6} \mathrm{Ni}_{0.2} \mathrm{Co}_{0.2}\right)_{1}-\mathrm{x} \mathrm{O}_{2}$ as cathode materials with outstanding performance for lithium-ion batteries. J Solid State Electrochem 20(1):95-103

10. Xiang Y, Yin Z, Li X (2014) Synthesis and characterization of manganese-, nickel-, and cobalt-containing carbonate precursors for high capacity Li-ion battery cathodes. J Solid State Electrochem 18:2123-2129

11. Sun H-H, Choi W, Lee JK, Oh I-H, Jung H-G (2015) Control of electrochemical properties of nickel-rich layered cathode materials for lithium ion batteries by variation of the manganese to cobalt ratio. J Power Sources 275:877-883

12. Yang $\mathrm{Z}, \mathrm{Lu} \mathrm{J}$, Bian D, Zhang w, Yang X, Xia J, Chen G, Gu H, Ma G (2014) Stepwise co-precipitation to synthesize $\mathrm{LiNi}_{1 / 3} \mathrm{Co}_{1 / 3} \mathrm{Mn}_{1 / 3} \mathrm{O}_{2}$ one-dimensional hierarchical structure for lithium ion batteries. J Power Sources 272:144-151

13. Li S, Ren Y, Biswas P, Tse SD (2016) Flame aerosol synthesis of nanostructured materials and functional devices: Processing, modeling, and diagnostics. Prog Energy Combust Sci 55:1-59

14. Konstantinov K, Ng SH, Wang JZ, Wang GX, Wexler D, Liu HK (2006) Nanostructured $\mathrm{PbO}$ materials obtained in situ by spray solution technique for Li-ion batteries. J Power Sources 159/1: 241-244

15. Lebl A, Andritz AG (2009) US Patent 7,597,873 B2

16. Zhang K, Li J, Li Q, Fang J, Zhang Z, Lai Y, Tian Y (2013) Synthesis of spherical porous carbon by spray pyrolysis and its application in Li-S batteries. J Solid State Electrochem 17: 3169-3175

17. Lengyel M, Atlas G, Elhassid D, Luo P, Zhang X, Belharouak I, Axelbaum RL (2014) Effects of synthesis conditions on the physical and electrochemical properties of $\mathrm{Li}_{1.2} \mathrm{Mn}_{0.54} \mathrm{Ni}_{0.13} \mathrm{Co}_{0.13} \mathrm{O}_{2}$ prepared by spray pyrolysis. $\mathrm{J}$ Power Sources 262:286-296

18. Taniguchi I (2005) Powder properties of partially substituted $\mathrm{LiM}_{\mathrm{x}} \mathrm{Mn}_{2}-\mathrm{xO}_{4}(\mathrm{M}=\mathrm{Al}, \mathrm{Cr}, \mathrm{Fe}$ and $\mathrm{Co})$ synthesized by ultrasonic spray pyrolysis. Mater Chem Phys 92/1:172-179

19. Oljaca M, Blizanac B, Pasquier AD, Sun Y, Bontchev R, Suszko A, Wall R, Koehlert K (2014) Novel $\mathrm{Li}\left(\mathrm{Ni}_{1 / 3} \mathrm{Co}_{1 / 3} \mathrm{Mn}_{1 / 3}\right) \mathrm{O}_{2}$ cathode morphologies for high power Li-ion batteries. J Power Sources 248: 729-738

20. Shui M, Gao S, Zheng W, Xu D, Chen L, Feng L, Ren Y (2013) $\mathrm{LiNi}_{1 / 3} \mathrm{Co}_{1 / 3} \mathrm{Mn}_{1 / 3} \mathrm{O}_{2}$ cathode materials for LIB prepared by spray pyrolysis I: the spectral, structural, and electro-chemical properties. Ionics 19/1:41-46

21. Kim MG, Shin HJ, Kim J-H, Park S-H, Sun Y-K (2005) XAS Investigation of Inhomogeneous Metal-Oxygen Bond Covalency in Bulk and Surface for Charge Compensation in Li-Ion Battery Cathode $\mathrm{Li}\left[\mathrm{Ni}_{1}{ }_{3} \mathrm{Co}_{1}{ }_{3} \mathrm{Mn}_{1}{ }_{3}\right] \mathrm{O}_{2}$ Material Batteries, Fuel Cells, and Energy Conversion. J Electrochem Soc 152/7:A1320-A1328

22. Park SH, Yoon CS, Kang SG, Kim H-S, Moon S-I, Sun Y-K (2004) Synthesis and structural characterization of layered $\mathrm{Li}\left[\mathrm{Ni}_{1 / 3} \mathrm{Co}_{1 / 3} \mathrm{Mn}_{1 / 3}\right] \mathrm{O} 2$ cathode materials by ultrasonic spray pyrolysis method. Electrochim Acta 49/4:557-563

23. Harris LJF (1994) Introduction to spray roasting process for hydrochloric acid regeneration and its application to mineral processing. Hydrometallurgy 923-937. doi:10.1007/978-94-011-1214-7_62

24. Peek EML (1995) Chloride pyrohydrolysis, lixiviant regeneration and metal separation. Doctoral thesis, Delft University of Technology

25. Larson AC, Von Dreele RB (1987) Los Alamos National Laboratory report, no. LAUR-86-748.

26. Toby BH (2001) EXPGUI, a graphical user interface for GSAS. J Appl Crystallogr 34:210

27. Nazar LF, Swainson I, Rho Y-H, Yin S-C (2006) X-ray/Neutron Diffraction and Electrochemical Studies of Lithium De/ReIntercalation in $\mathrm{Li}_{1-\mathrm{x}} \mathrm{Co}_{1 / 3} \mathrm{Ni}_{1 / 3} \mathrm{Mn}_{1 / 3} \mathrm{O}_{2}(\mathrm{x}=0 \rightarrow 1)$. Chem Mater 18:1901

28. Myung ST, Komaba S, Kurihara K, Hosaya K, Kumagai N, Sun YK, Nakai I, Yonemura M, Kamiyama T (2006) Synthesis of $\mathrm{Li}\left[\left(\mathrm{Ni}_{0.5} \mathrm{Mn}_{0.5}\right)_{1-\mathrm{x}} \mathrm{Li}_{\mathrm{x}}\right] \mathrm{O}_{2}$ by emulsion drying method and impact of excess $\mathrm{Li}$ on structural and electrochemical properties. Chem Mater 18:1658-1666

29. Balakirev VF, Barkhatov VP, Golikov YV, Maizel SG (1999) Manganites: equilibrium and unstable states. UD RAS, Yekaterinburg in Russian 